\title{
Front Matter: Volume 10243
}

, "Front Matter: Volume 10243," Proc. SPIE 10243, X-ray Lasers and Coherent X-ray Sources: Development and Applications, 1024301 (20 July 2017); doi: 10.1117/12.2282016

SPIE. Event: SPIE Optics + Optoelectronics, 2017, Prague, Czech Republic 


\title{
PROCEEDINGS OF SPIE
}

\section{$X$-ray Lasers and Coherent X-ray Sources: Development and Applications}

\author{
Annie Klisnick \\ Carmen S. Menoni \\ Editors
}

\section{4-26 April 2017 \\ Prague, Czech Republic}

Sponsored by

SPIE

Cooperating Organisations

Science and Technology Facilities Council (United Kingdom)

ELI Beamlines (Czech Republic)

Laserlab Europe

AILU-Association of Laser Users (United Kingdom)

European Optical Society

HiLASE (Czech Republic)

AWE-Atomic Weapons Establishment (United Kingdom)

Published by

SPIE 
The papers in this volume were part of the technical conference cited on the cover and title page. Papers were selected and subject to review by the editors and conference program committee. Some conference presentations may not be available for publication. Additional papers and presentation recordings may be available online in the SPIE Digital Library at SPIEDigitalLibrary.org.

The papers reflect the work and thoughts of the authors and are published herein as submitted. The publisher is not responsible for the validity of the information or for any outcomes resulting from reliance thereon.

Please use the following format to cite material from these proceedings:

Author(s), "Title of Paper," in X-ray Lasers and Coherent X-ray Sources: Development and Applications, edited by Annie Klisnick, Carmen S. Menoni, Proceedings of SPIE Vol. 10243 (SPIE, Bellingham, WA, 2017) Seven-digit Article CID Number.

ISSN: 0277-786X

ISSN: 1996-756X (electronic)

ISBN: 9781510609877

ISBN: 9781510609884 (electronic)

Published by

SPIE

P.O. Box 10, Bellingham, Washington 98227-0010 USA

Telephone +1 3606763290 (Pacific Time) · Fax +1 3606471445

SPIE.org

Copyright @ 2017, Society of Photo-Optical Instrumentation Engineers.

Copying of material in this book for internal or personal use, or for the internal or personal use of specific clients, beyond the fair use provisions granted by the U.S. Copyright Law is authorized by SPIE subject to payment of copying fees. The Transactional Reporting Service base fee for this volume is $\$ 18.00$ per article (or portion thereof), which should be paid directly to the Copyright Clearance Center (CCC), 222 Rosewood Drive, Danvers, MA 01923. Payment may also be made electronically through CCC Online at copyright.com. Other copying for republication, resale, advertising or promotion, or any form of systematic or multiple reproduction of any material in this book is prohibited except with permission in writing from the publisher. The CCC fee code is $0277-786 \mathrm{X} / 17 / \$ 18.00$.

Printed in the United States of America.

\section{Publication of record for individual papers is online in the SPIE Digital Library. SPIE. DIBRARY \\ SPIEDigitalLibrary.org}

Paper Numbering: Proceedings of SPIE follow an e-First publication model. A unique citation identifier (CID) number is assigned to each article at the time of publication. Utilization of CIDs allows articles to be fully citable as soon as they are published online, and connects the same identifier to all online and print versions of the publication. SPIE uses a seven-digit CID article numbering system structured as follows:

- The first five digits correspond to the SPIE volume number.

- The last two digits indicate publication order within the volume using a Base 36 numbering system employing both numerals and letters. These two-number sets start with 00,01, 02, 03, 04, 05, 06, 07, 08 , $09,0 A, O B \ldots 0 Z$, followed by 10-1Z, 20-2Z, etc. The CID Number appears on each page of the manuscript. 


\title{
Contents
}

\author{
$\checkmark$ Authors \\ vii Conference Committee \\ ix Introduction
}

SESSION 1 LABORATORY-SCALE SOFT X-RAY LASERS AND COHERENT X-RAY SOURCES

1024303 DAGON: a 3D Maxwell-Bloch code [10243-2]

SESSION 2 SOFT X-RAY APPLICATIONS I

1024307 Thomson scattering laser-electron $x$-ray source for reduction of patient radiation dose in interventional coronary angiography [10243-6]

1024308 Optimizing soft x-ray NEXAFS spectroscopy in the laboratory [10243-7]

1024309 Soft $\mathrm{x}$-ray nanoscale imaging using highly brilliant laboratory sources and new detector concepts (Invited Paper) [10243-8]

\section{SESSION 3 NEW CONCEPTS FOR HIGH-BRIGHTNESS X-RAY SOURCES}

10243 OC Using the XFEL to drive gain in L-shell systems using photoionization processes [10243-11]

10243 OD Amplified spontaneous and stimulated $\mathbf{M g} \mathrm{L}$ emissions from $\mathrm{MgO}$ pumped by FEL pulses [10243-12]

\section{SESSION 4 LABORATORY-SCALE SOFT X-RAY LASERS AND APPLICATIONS}

10243 OF Progress in high repetition rate soft $x$-ray laser development and pump lasers at Colorado State University (Invited Paper) [10243-14]

$102430 G$ Soft $x$-ray ablation mass spectrometry: high sensitivity elemental trace analysis [10243-15]

10243 ol Table-top two-color soft x-ray laser from Ni-like Mo plasma (Invited Paper) [10243-17] 
SCIENTIFIC APPLICATIONS OF LASER- AND ACCELERATOR-BASED X-RAY SOURCES: JOINT SESSION WITH CONFERENCES 10237 AND 10243

10243 OK Time-resolved $x$-ray spectroscopy for $x$-ray-induced phenomena [10243-19]

$10243 \mathrm{OL}$ The EIS beamline at the seeded free-electron laser FERMI [10243-20]

\section{SESSION 5 SOFT X-RAY APPLICATIONS II}

1024300 Soft $x$-ray imaging with incoherent sources (Invited Paper) [10243-23]

10243 OP X-ray absorption spectroscopy probing hydrogen in metals [10243-24]

$102430 Q \quad$ Laser plasma soft $x$-ray source based on cryogenic target (Invited Paper) [10243-25]

10243 OS Soft x-ray laser ablation of metals and dielectrics (Invited Paper) [10243-27]

\section{SESSION 6 HIGH-ORDER HARMONICS AND APPLICATIONS}

$10243 \mathrm{OV}$ Tunable orbital angular momentum beams in the extreme ultraviolet/soft $\mathrm{x}$-ray regimes [10243-30]

POSTER SESSION

10243 OX Resolution of x-ray parabolic compound refractive diamond lens defined at the home laboratory [10243-32]

10243 OY Evaluation of laser-electron $x$-ray source and related optics for x-ray diffractometry and topography [10243-33]

1024315 XUV generation from the interaction of pico- and nanosecond laser pulses with nanostructured targets [10243-41] 


\section{Authors}

Numbers in the index correspond to the last two digits of the seven-digit citation identifier (CID) article numbering system used in Proceedings of SPIE. The first five digits reflect the volume number. Base 36 numbering is employed for the last two digits and indicates the order of articles within the volume. Numbers start with 00, 01, 02, 03, 04, 05, 06, 07, 08, 09, OA, OB...0Z, followed by 10-1Z, 20-2Z, etc.

\author{
Amano, Sho, $0 Q$ \\ André, Jean-Michel, OD \\ Arbelo Pena, Yunieski, OP \\ Artyukov, I. A., 07, OY \\ Ayele, M., 00 \\ Barbato, Francesco, OP \\ Barte, Ellie Floyd, 15 \\ Bartnik, A., 00 \\ Baumgarten, Cory, OF \\ Bencivenga, F., OL \\ Berrill, Mark, OF \\ Blank, V. D., OX, OY \\ Bleiner, Davide, OI, OP \\ Borgschulte, Andreas, OP \\ Braenzel, J., 09 \\ Calvi, A., OL \\ Chao, W., OG \\ Cirelli, Claudio, OP \\ Cotelo, Manuel, 03 \\ Czwartos, J., 00 \\ Dal Zilio, S., OL \\ Dehlinger, A., 09 \\ Delmelle, Renaud, OP \\ Denisov, V. N., OX \\ Duffin, A. M., OG \\ Dunne, Padraig, 15 \\ Dyachkov, N. V., 07 \\ Escudero, Juan Carlos, 03 \\ Faenov, A., OS \\ Fava, C., OL \\ Feshchenko, R. M., 07, OY \\ Fiedorowicz, H., $0 \mathrm{O}$ \\ Foglia, L., OL \\ Fok, T., 00 \\ Gasilov, S. V., OX \\ Gerusina, S., OL \\ Gessini, Alessandro, OD \\ Gobessi, R., OL \\ González-Fernández, Agustín, 03 \\ Green, T., OG \\ Hasegawa, N., OS \\ Hernández-García, Carlos, OV \\ Inogamov, N., OS \\ Ishino, M., OS \\ Jonas, A., 08 \\ Jonnard, Philippe, OD \\ Jung, R., 08, 09 \\ Kando, M., OS \\ Kanngießer, B., 08
}

\author{
Kawachi, T., OS \\ Kodama, R., OS \\ Kos, Domagoj, 15 \\ Kurdi, G., OL \\ Kuznetsov, I., OG \\ Kyaw, C. N., OF \\ Le Guen, Karine, OD \\ Limpouch, Jiri, 15 \\ Lokasani, Ragava, 15 \\ Luebcke, A., 09 \\ Maguire, Oisin, 15 \\ Mahne, N., OL \\ Manfredda, M., OL \\ Mantouvalou, I., 08 \\ Marconi, Mario C., OF \\ Martyushov, S. YU., OX \\ Masciotti, $\mathrm{V} ., \mathrm{OL}$ \\ Masciovecchio, Claudio, OD, OL \\ Matruglio, A., OL \\ McCormack, Tom, 15 \\ Menoni, Carmen S., OF, OG \\ Mincigrucci, Riccardo, OD, OL \\ Nilsen, Joseph, OC \\ Nishikino, M., OS \\ O'Reilly, Fergal, 15 \\ O'Sullivan, Gerry, 15 \\ Odstrcil, M., 00 \\ Oliva, Eduardo, 03 \\ Parkman, T., 00 \\ Patterson, Bruce, OP \\ Pedicone, Michael, OF \\ Peyrusse, Olivier, OD \\ Picón, Antonio, OK, OV \\ Pikuz, T., OS \\ Plaja, Luis, OV \\ Polunina, A. V., 07 \\ Polyakov, S. N., OX, OY \\ Popov, N. L., 07, OY \\ Principi, Emiliano, OD, OL \\ Proska, Jan, 15 \\ Raimondi, L., OL \\ Reagan, Brendan A., OF \\ Regehly, M., 09 \\ Rego, Laura, OV \\ Ritter, S., 09 \\ Rocca, Jorge J., OF, OG \\ Sambalova, Olga, OP \\ Sanchís, Alberto, 03 \\ San Román, Julio, OV
}


Schnuerer, M., 09

Seim, C., 09

Sheridan, Paul, 15

Shlyaptsev, Vyacheslav N., OF

Shvedunov, V. I., 07

Simoncig, Alberto, OD, OL

Skobelev, I., OS

Sokell, Emma, 15

Stiel, H., 08, 09

Stolcova, Lucie, 15

Terentiev, S. A., OX

Torrisi, A., 00

Tuemmler, J., 09

Turnová, J., 00

Turpin, Alex, OV

Velarde, Pedro, 03

Vera, Javier, 03

Vicéns, Sergio, 03

Vinogradov, A. V., 07, OY

Vondrová, Š., 00

Wachulak, P., 00

Wang, Hanchen, OF

Wang, Shoujun, OF

Wang, Yong, OF

Węgrzyński, Ł., 00

Witte, K., 08

Wu, Meiyi, OD

Yaroslavtsev, A. A., OY

Yin, Liang, OF

Zangrando, M., OL

Zhakhovsky, V., OS

Zholudev, S. I., OX, OY 


\title{
Conference Committee
}

\author{
Symposium Chairs
}

Jiri Homola, Institute of Photonics and Electronics of the ASCR, v.v.i. (Czech Republic)

Bedrich Rus, Institute of Physics of the ASCR, v.v.i. (Czech Republic)

Chris Edwards, Central Laser Facility, Science and Technology

Facilities Council (United Kingdom)

Mike Dunne, SLAC National Accelerator Laboratory (United States), and Linac Coherent Light Source (United States)

Ivo Rendina, Istituto per la Microelettronica e Microsistemi, CNR (Italy)

\section{Conference Chairs}

Annie Klisnick, CNRS, Université Paris-Sud 11 (France)

Carmen S. Menoni, Colorado State University (United States)

\section{Conference Programme Committee}

Jens Biegert, ICFO - Institut de Ciències Fotòniques (Spain)

Hiroyuki Daido, Japan Atomic Energy Agency (Japan)

Yasin Ekinci, Paul Scherrer Institut (Switzerland)

Sylvie Jacquemot, Ecole Polytechnique (France)

Do-Kyeong Ko, Gwangju Institute of Science and Technology

(Korea, Republic of)

Michaela Kozlová, Institute of Physics of the ASCR, v.v.i.

(Czech Republic)

Ciaran L. S. Lewis, Queen's University Belfast (United Kingdom)

Stefan P. Moeller, SLAC National Accelerator Laboratory (United States)

Peter Viktor Nickles, Gwangju Institute of Science and Technology

(Korea, Republic of)

Joseph Nilsen, Lawrence Livermore National Laboratory (United States)

Jorge J. Rocca, Colorado State University (United States)

Regina Soufli, Lawrence Livermore National Laboratory

(United States)

Szymon Suckewer, Princeton University (United States)

Gregory J. Tallents, The University of York (United Kingdom)

Alexander Vladimirovich Vinogradov, P.N. Lebedev Physical Institute (Russian Federation)

Marco Zangrando, Sincrotrone Trieste S.C.p.A. (Italy) 
Laboratory-scale Soft X-ray Lasers and Coherent X-ray Sources

Jorge J. Rocca, Colorado State University (United States)

Soft X-Ray Applications I

Michaela Kozlová, Institute of Physics of the ASCR, v.v.i.

(Czech Republic)

New Concepts for High-Brightness X-ray Sources

Stéphane Sebban, Centre National de la Recherche Scientifique (France)

Laboratory-scale Soft X-ray Lasers and Applications

Sylvie Jacquemot, Laboratoire pour l'Utilisation des Lasers Intenses (France)

Scientific Applications of Laser- and Accelerator- based X-ray

Sources: Joint Session with Conferences 10237 and 10243

Thomas Tschentscher, European XFEL GmbH (Germany)

Temporal, Spatial and Coherence Diagnostics of Ultrashort X-ray Pulses: Joint Session with Conferences 10237 and 10243

Carmen S. Menoni, Colorado State University (United States)

Soft X-Ray Applications II

Hyung Taek Kim, Gwangju Institute of Science and Technology

(Korea, Republic of)

High-order Harmonics and Applications

Joseph Nilsen, Lawrence Livermore National Laboratory

(United States)

High Brightness and Ultrashort X-ray and EUV Sources: Joint Session with Conferences 10237 and 10243

Annie Klisnick, Université Paris-Sud 11 (France) 


\section{Introduction}

The X-ray Lasers and Coherent X-ray Sources: Development and Applications conference was held in Prague, Czech Republic on April 24-27, 2017. The conference was part of the SPIE Optics and Optoelectronics Conference that attracts 16 other topical conferences, some of which complement the topics covered by X-ray Lasers and Coherent X-ray Sources: Development and Applications. The conference gathered an international group of participants that through invited and contributed talks described the most recent developments in the generation and applications of intense $X$-rays from plasmabased $x$-ray lasers, $4^{\text {th }}$ generation accelerator-based sources and high-order harmonic $(\mathrm{HOH})$ generation. Three joint sessions on accelerator based sources, metrology and applications were co-organized with SPIE conference 10237 " $X$ Ray Free Electron Lasers: Advances in Source Development and Applications". There were also several sessions that described the state-of-the art in optics and applications of these sources in imaging and spectroscopies.

Work presented at the conference showed significant advances of plasma based $x$-ray lasers. Seeding of $x$-ray laser amplifiers with high order harmonics $(\mathrm{HOH})$ is providing opportunities to control polarization, realize full spatial coherence and potentially achieve femtosecond pulse duration. Besides already demonstrated high average power, plasma based $\mathrm{x}$-ray lasers have reached output wavelengths down to $6.89 \mathrm{~nm}$ with micro-joule pulse energies suited for applications. Some high energy laser facilities already established and others that are projected to come into operation in the next few years are paving the way to further the development of plasma based $x$-ray lasers as well as other coherent high brightness $\mathrm{x}$-ray sources.

The conference held three joint sessions on "Scientific Applications of Laser- and Accelerator-based X-ray Sources," "Temporal, Spatial and Coherence Diagnostics of Ultrashort X-ray Pulses," and "High Brightness and Ultrashort X-ray and EUV Sources," with SPIE Conference 10237 that were very well attended. Seeding of Free Electron Lasers to control coherence, reaching attosecond pulse durations and generating high quality electron beams to improve FEL output were discussed. Diagnostics of the temporal, spatial and coherence properties of the x-ray sources' output incentivized interest from the whole community as precise diagnostics of the output of coherent $\mathrm{x}$-ray sources is critical for applications.

The sessions in applications highlighted important advances in imaging, and spectroscopy that are impacting materials science and biology. Access to excitation of inner shell electrons in atoms and molecules with the energetic X-ray photons has enabled the implementation of absorption, near edge and photoelectron emission spectroscopies some of which are exploiting the short 
pulse duration of the x-ray emission to track ultrafast dynamics, such as in bond breaking. Advances in high resolution x-ray imaging using different geometries that include lensless, phase contrast imaging, holography and aerial geometries using table-top x-ray lasers, $\mathrm{HOH}$ and incoherent sources were presented. The control of polarization in $\mathrm{HOH}$ and plasma and accelerator based soft $x$-ray lasers, the ability to generate phase vortices with advanced optics or by tailoring the driving laser output as in $\mathrm{HOH}$ as presented at the conference will have a significant impact in broadening the application's landscape.

We gratefully acknowledge the continued support of SPIE for the field of x-ray lasers. The outstanding organization of the conference at all stages as well as the efforts of the staff towards the publication of the proceedings volume is also acknowledged. We would like to thank the Program Committee for their support and guidance and to the session chairs for their help in the running of the conference. Finally we thank the many participants for their high quality scientific contributions to the 2017 meeting.

Annie Klisnick Carmen S. Menoni 